\title{
MEMBATIK DI DESA TORONGREJO KOTA BATU
}

\author{
${ }^{1)}$ Sumanto, ${ }^{2)}$ Hardiyanto, ${ }^{3)}$ Basuki Widodo, ${ }^{4)}$ Nyoman Sudiasa \\ ${ }^{1)}$ Prodi Teknik Industri, Fakultas Teknologi Industri, Institut Teknologi Nasional Malang \\ ${ }^{2)}$ Prodi Teknik Lingkungan, Fakultas Teknik Sipil dan Perencanaan, Institut Teknologi Nasional Malang \\ ${ }^{3)}$ Prodi Teknik Mesin, Fakultas Teknologi Industri, Institut Teknologi Nasional Malang \\ ${ }^{4)}$ Prodi Teknik Sipil, Fakultas Teknik Sipil dan Perencanaan, Institut Teknologi Nasional Malang
}

\begin{abstract}
Abstrak, Desa Torongrejo juga mempunyai Lembaga Pemberdayaan Masyarakat Desa (LPMD) yang mencoba membantu untuk meningkatkan kemandirian masyarakat Desa dan meningkatkan ekonomi masyarakat desa. Dalam pelaksanaannya, LPMD bersinergi dengan Karang Taruna Desa Torongrejo Kota Batu. Salah satu program kerja dari karang taruna ini adalah meningkatkan kemandirian usaha di mana masing-masing anggota dapat menciptakan usaha baik perorangan maupun kelompok. Salah satu keterampilan yang diharapkan dapat meningkatkan kemandirian tersebiut adalah usaha pembuatan batik. Hal ini sejalan dengan program Pemerintah Kota Batu yaitu melestarikan warisan budaya bangsa yaitu batik. sehubungan dengan hal ini pemerintah Kota Batu telah membagikan kain batik khas Kota Batu kepada siswa-siswi sebagai seragam sekolah dari tingkat SD/MI sampai dengan tingkat SMA/SMK/MA. Salah satu kendala yang dihadapi oleh Karang Taruna untuk mewujudkan target ini adalah tidak adanya instruktur membatik. Melihat kondisi seperti ini maka Tim Pengabdi Kepada Mayarakat ITN Malang di bawah LPPM ITN Malang mengadakan pelatihan pembuatan batik bagi Anggota Karang Taruna Desa Torongrejo Kota Batu pada tanggal 13 Agustus 2017 yang diikuti oleh 13 peserta dari 20 yang diharapkan. Pelatihan diikuti dengan antusias oleh peserta, terbukti dengan waktu yang panjang mereka dengan sabar dan teliti dapat menyelesaikan satu lembar kain batik sebagai hasil pelatihan membatik.
\end{abstract}

Kata Kunci: batik, Desa Torongrejo

Desa Torongrejo secara administrasi pemerintahan merupakan bagian dari Kecamatan Junrejo Kota Batu. Desa Torongrejo berbatasan langsung dengan Desa Beji dan Mojorejo di sebelah selatan, di sebelah timur berbatasan dengan Desa Pendem, di sebelah utara berbatasan dengan Desa Giripurno dan Desa Pandarejo dan di sebelah barat berbatasan dengan desa Temas. Mayoritas pekerjaan masyarakat Desa Torongrejo adalah petani.

Desa Torongrejo juga mempunyai Lembaga Pemberdayaan Masyarakat Desa (LPMD) yang mencoba membantu untuk meningkatkan kemandirian masyarakat Desa dan meningkatkan ekonomi masyarakat desa. Dalam pelaksanaannya, LPMD bersinergi dengan Karang Taruna Desa Torongrejo Kota Batu. Salah satu program kerja dari karang taruna ini adalah meningkatkan kemandirian usaha di mana masing-masing anggota dapat menciptakan usaha baik perorangan maupun kelompok.

Salah satu keterampilan yang diharapkan dapat meningkatkan kemandirian tersebiut adalah usaha pembuatan batik. Hal ini sejalan dengan program Pemerintah Kota Batu yaitu melestarikan warisan budaya bangsa yaitu batik. sehubungan dengan hal ini pemerintah Kota Batu telah membagikan kain batik khas Kota Batu kepada siswa-siswi sebagai seragam sekolah dari tingkat SD/MI sampai dengan tingkat SMA/SMK/MA. Salah satu kendala yang dihadapi oleh Karang Taruna untuk mewujudkan target ini adalah tidak adanya instruktur membatik, sehingga sangat tepat jika Tim Pengabdi Kepada Masyarakat ITN Malang bergerak melatih para anggota Karang Taruna Desa Torongrejo Kota Batu dalam pembuatan batik

Batik

Batik adalah kain bergambar yang pembuatannya secara khusus dengan menuliskan atau menerakan malam pada kain itu, kemudian pengolahannya diproses dengan cara tertentu yang memiliki kekhasan. Batik Indonesia, sebagai keseluruhan teknik, teknologi, serta pengembanganmotif dan budaya yang terkait, oleh UNESCO telah ditetapkan sebagai Warisan Kemanusiaan untuk Budaya Lisan dan Nonbendawi (Masterpieces of the Oral and Intangible Heritage of Humanity) sejak 2 Oktober 2009.

Jenis-jenis Batik 
Menurut cara membuatnya, batik dibagi menjadi 3 (tiga) bagian yaitu:

1. Batik tulis adalah kain yang dihias dengan teksture dan corak batik menggunakan tangan. Pembuatan batik jenis ini memakan waktu kurang lebih 2-3 bulan.

2. Batik cap adalah kain yang dihias dengan teksture dan corak batik yang dibentuk dengan cap ( biasanya terbuat dari tembaga). Proses pembuatan batik jenis ini membutuhkan waktu kurang lebih 2-3 hari.

3. Batik lukis adalah proses pembuatan batik dengan cara langsung melukis pada kain putih.

\section{Alat dan Bahan}

Alat dan bahan yang digunakan dalam pembuatan batik adalah:

1. Kain Mori (bias terbuat dari sutra, katun, atau campuran kain polyester)

2. Pensil

3. Canting (bias dikatakan ini adalah alat tulis batik)

4. Gawangan (tempat sampiran kain ketika membatik)

5. Lilin/malam cair

6. Panci kecil (untuk tempat lilin/malam)

7. Kompor kecil (untuk memanaskan lilin/malam)

8. Larutan pewarna

\section{Langlah-langkah Pembuatan kain Batik}

1. Pertama, kita buat dahulu desain batik dgn menggunakan pensil. Desain batik ini disebut molani. Untuk pembatik yg "expert", dia bisa membuat motif batik sendiri, tapi untuk pemula disarankan untuk mengikuti motif-motif umum yg telah ada saja dahulu.

2. Setelah pembuatan molani selesai, langkah selanjutnya adalah melukis dgn lilin cair dgn menggunakan canting dgn mengikuti pola yg tadi dibuat.

3. Menutup dgn lilin bagian-bagian yg akan tetap tidak berwarna. Gunakan canting pada bagian yg mendetail, dan gunakan kuas pada area yg besar.

4. Tahap keempat adalah proses pewarnaan dgn cara mencelupkan kain tersebut ke larutan pewarna tertentu.

5. Kain yg telah dicelupkan dijemur sampai kering.

6. Jika kita menginginkan beberapa warna pada batik yg kita buat, maka proses
7. Langkah 3, 4, dan 5 bisa diulang beberapa kali tergantung jumlah warna yg kita inginkan.

8. Setelah itu adalah proses nglorot, dimana kain yg telah berubah warna tadi direbus dgn air panas. Proses ini bertujuan untuk menghilangkan lapisan lilin sehingga motif yg telah digambar menjadi terlihat jelas.

9. Kain batik tadi tentu perlu dicuci supaya bersih, ini adalah proses terakhir dari pembuatan batik yaitu mencuci kemudian keringkan dgn cara dijemur.

\section{METODE PELAKSANAAN}

Metode kegiatan ini diawali dengan observasi kondisi dan situasi Desa Torongrejo Kota Batu dilajutkan dengan koordinasi dengan pihak-pihak terkait di Desa Torongrejo. Setelah mendapatkan gambaran kondisi di Desa Torongrejo, maka dilakukan persiapanpersiapan untuk melakukan pelatihan pembuatan pembuatan batik. Setelah dilaksanakan pelatihan dilakukan evaluasi kegiatan.

\section{HASIL DAN PEMBAHASAN}

Kegiatan pelatihan dilaksanakan pada tanggal 13 Agustus 2017 diikuti oleh 13 peserta dari 20 orang peserta yang diharapkan. Peserta pelatihan ini adalah anggota Karang Taruna Desa Torongrejo Dusun Klerek Kota Batu.

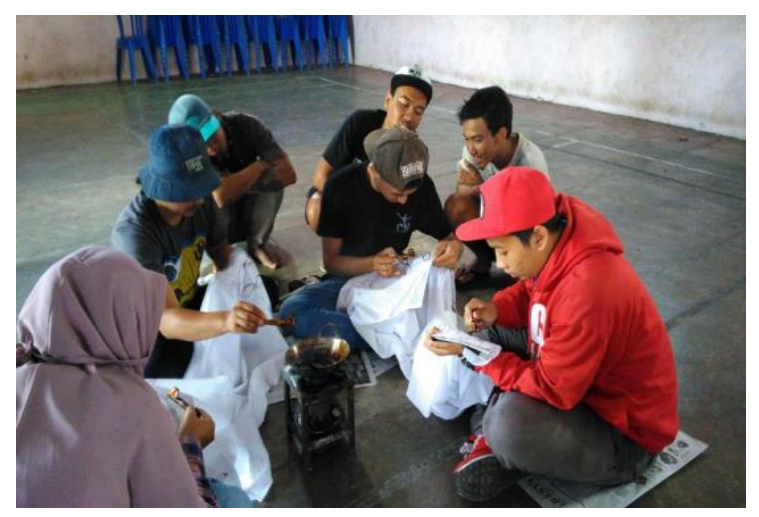



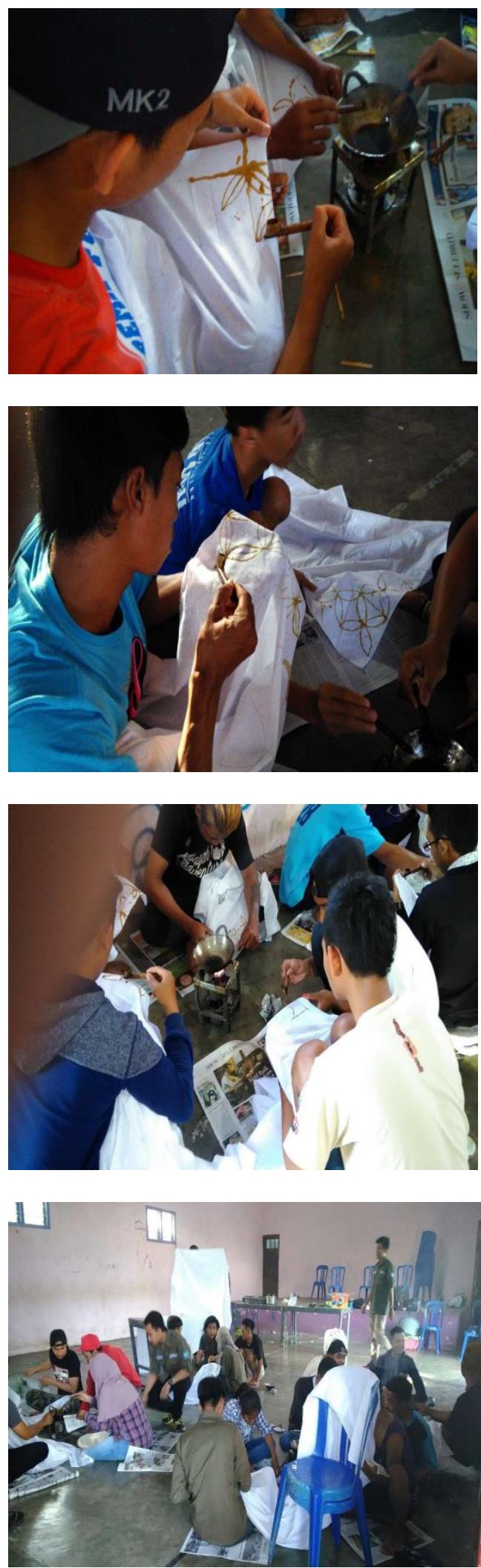
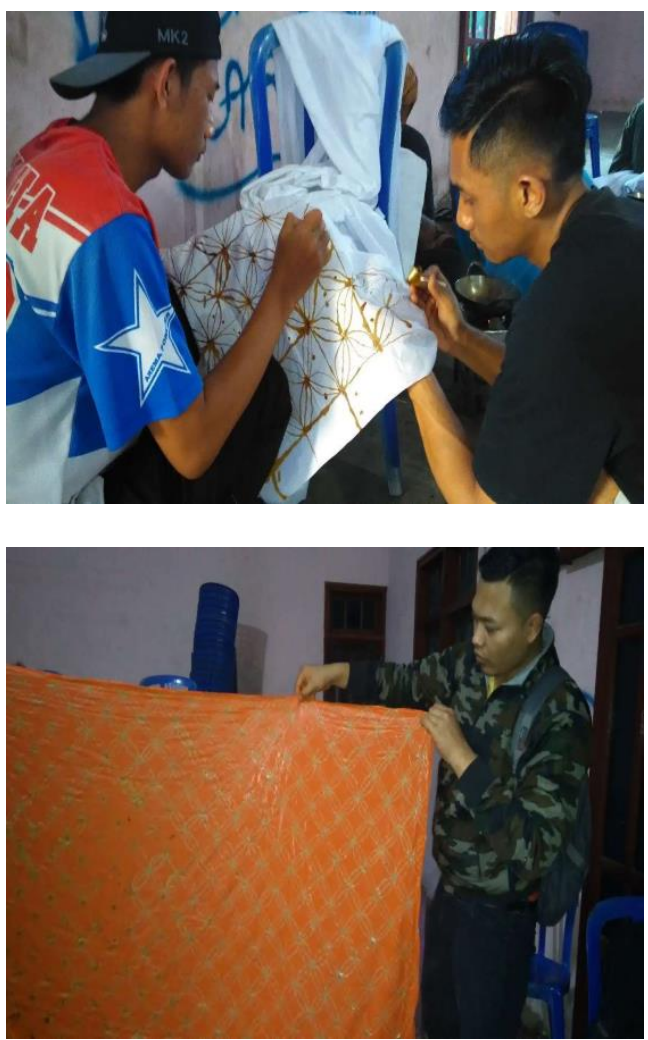

Kegiatan pelatihan pembuatan batik ini mendapatkan apresiasi dari peserta. Mereka mula-mula berpikir bahwa pekerjaan menbuat batik merupakan pekerjaan yang sulit. Ketika diajarkan teknik membatik yang baik mereka dapat mengerjakannya dengan baik pula sehingga anggapan bahwa membatik adalah sulit terbantahkan.

Peserta sangat antusias mengikuti kegiatan ini, meskipun kegiatan ini dilaksanakan dengan durasi waktu yang sangat lama dan sampai malam hari, mereka tetap semangat dan menyelesaikan tugasnya dengan baik.

Peserta berharap dalam pembuatan batik sebagai usaha untuk meningkatkan kesejahteraan ekonomi dapat dibimbing dan di dampingi oleh instruktur yang ahli dalam bidang batik. Karena hasil dari usaha ini diharapkan dapat meningkatkan kesejahtaeraan msyarakat Desa torongrejo Kota Batu dari segi ekonomi. 


\section{KESIMPULAN DAN SARAN}

\section{Kesimpulan}

Pelatihan pembuatan batik yang dilaksanakan di Desa Torongrejo Kecamatan Junrejo Kota Malang berjalan lancar diikuti oleh 13 orang anggota karang taruna. Jumlah peserta yang hadir belum mencapai target dari 20 orang yang diundang. Tetapi respon dari yang mengikuti pelatihan sangat baik dan berharap diikuti dengan pelatihan selanjutnya.

Saran

Berdasarkan hasil pelatihan, dapat disarankan sebagai berikut:

1. Ada pembinaan dan pendampingan berkaitan dengan usaha produksi batik

2. Pelatihan serupa dapat ditindaklanjuti dengan pembinaan dan pendampingan usaha pembuatan batik di Desa Torongrejo Kota.

\section{DAFTAR PUSTAKA}

1. Lieny Wulandari. Alat dan Bahan Pembuat Batik Tulis. https://www.academia.edu/10355725/A lat Dan Bahan Pembuatan Batik Tul is

2. Sherly Iskandar. Ketahui Berbagai Jenis Batik dari Berbagai Daerah di Indonseia. http://www.bintang.com/lifestyle/read/ 2332002/ketahui-jenis-motif- batikdari-berbagai-daerah-di-indonesia

3. https://id.wikipedia.org/wiki/Batik Batik.

4. Proses Pembuatan Batik. https://batik.kompas.id/panorama 